\title{
Aerobic Bacteria Isolates of Septic Wound Infections and Their Antibiogram in North Central Nigeria
}

\author{
James Garba Damen ${ }^{1, ~ *, ~ S a l a m i ~ F a r u k ~}{ }^{1}$, Comfort Dancha ${ }^{2}$ \\ ${ }^{1}$ Department of Medical laboratory Science College of Medical Science, University of Jos, Nigeria \\ ${ }^{2}$ Medical Laboratory Services Department, Federal Polytechnic Mubi, Adamawa state, Nigeria
}

Email address:

Jamesgdamen@yahoo.com (J. G. Damen), damenj@unijos.edu.ng (J. G. Damen)

\section{To cite this article:}

James Garba Damen, Salami Faruk, Comfort Dancha. Aerobic Bacteria Isolates of Septic Wound Infections and Their Antibiogram in North Central Nigeria. American Journal of Biomedical and Life Sciences. Vol. 3, No. 3, 2015, pp. 36-40. doi: 10.11648/j.ajbls.20150303.12

\begin{abstract}
Background: Wound infections are major problem in our health care facilities. They are the most common hospital acquired infections resulting into extended length of stay in the hospital with high cost and frequently encounter in surgical patients. Objectives: The study was designed to determine aerobic bacterial pathogens responsible for wound infections and their antibiotic sensitivity profile among patients of Jos University Teaching Hospital (JUTH).Methods: Wound swabs were aseptically collected randomly from septic wounds of 345 patients in different sections of the hospital; they were cultured on Blood Agar (BA), McConkey Agar (MCA) and chocolate Aga (CA) and incubated aerobically over night, direct Gram stain were carried out on the wound swabs. The isolates were also examined by Gram stain and each of them were identified using standard biochemical methods. The antibiotic susceptibility of each pathogen was carried out using the disc diffusion method on Muller Hinton Agar. Results: A total of 345 wound swabs were collected and examined, 243 (70.4\%) aerobic bacteria were isolated. The out patients had the highest prevalent of $85.3 \%$ positive while the least prevalent of $50.0 \%$ was recorded from female medical patients. The males had the highest prevalent of $82.1 \%$ while $55.0 \%$ of medical females were positive for bacteria. Staphylococcus aureus was the highest bacteria reported while the least prevalent of bacteria was Pseudomonas aeruginosa (9.7\%). Ofloxacin was highly sensitive for all the bacteria isolated while Amoxicillins, penicilins and cotrimoxazole recorded reduced sensitivity to the isolates. Conclusion: Aerobic bacteria are highly predominant in septic wound and most of the bacteria are resistant to commonly used antibiotics which might be due to inadequate wound management, poor antibiotics selection in most parts of the hospital; and indiscriminate use of antibiotics.
\end{abstract}

Keyword: Wound Aerobic, Bacteria, Infection

\section{Introduction}

Wound infection is important in the morbidity and mortality of patients irrespective of its cause; can delay healing and is associated with longer hospital stay thereby increasing cost of healthcare ${ }^{1}$. Wound infection is said to be the most common nosocomial infection ${ }^{2}$. Most wound infections can be classified into two major categories: skin and soft tissue infections, although they often overlap as a consequence of disease progression 3,4,5,6 Routine surveillance for hospital-acquired wound infections is recommended by both the Centers for Disease Control and Prevention $^{7}$ and the Surgical Infection Society ${ }^{8}$.In the developed world, studies on wound infections are focused on surgical sites infections because other types of wound infections are not problematic ${ }^{9,10,1}$ but in developing countries, other types of wound infections are very important causes of morbidity and mortality ${ }^{11,12,1}$. The prevalence rate of different bacterial in infected wounds varies ${ }^{13}$ it exists inter-institutionally and intra-institutionally ${ }^{14,15,16}$. Diagnoses of wound infections can be a serious problem in resourcepoor settings, due to inadequate diagnostic equipments or qualified profesionals ${ }^{17}$, resulting to the absence of important epidemiological data on wound infections and no established evidence-based guidelines to aid empiric treatment ${ }^{18}$. Bacterial resistance to antibiotics and the use of topical antiseptics for the treatment of wound infections has persisted and brought about the reemergence of alternative therapies and the search for new anti-microbial agents ${ }^{19}$. This study was designed to establish the current aerobic bacterial and their drug sensitivity in wound infections of patients at the Jos University Teaching Hospital, with a view to generate relevant data that will be of great benefit to the 
hospital's policies on selection of antibiotics for the management of wound infection.

\section{Materials and Methods}

\subsection{Study Area}

The study was conducted among both in and out patients with septic wounds attending Jos University Teaching Hospital (JUTH), Plateau State, North Central Nigeria

\subsection{Ethical Consideration}

Ethical clearance was sought and obtained from JUTH ethical committee before commencement of the study.

\subsection{Informed Consent}

The study was explained to each of the participants in simple Hausa or English and their informed consent were obtained before enrolment into the study. Structured questionnaires which content information on age, sex, department, type of wound infection, sources of wound infection and presence/absence of discharges and history of antibiotics treatment were administered to each of the consented participant.

\subsection{Inclusion and Exclusion Criteria}

Patients with wounds that show signs of infection were eligible for the study while those with wound that were not septic and almost healing up were excluded from the study..

\subsection{Sample Collection}

Sterile swab sticks were used to collect 345 wound swabs under aseptic procedures and were send to the Microbiology for cultivation.

\subsection{Culture Media}

Culture media used in this study were prepared according to the manufacturer's instructions, they include; Blood Agar (BA), MacConkey Agar (MCA), Chocolate Agar (CA) and Muller Hinton agar $^{20}$

\subsection{Cultivation}

The wound swabs were immediately cultured onto Blood agar, chocolate agar and McConkey agar, the specimen were streaked out carefully for discrete colonies and were incubated at $37^{\circ} \mathrm{c}$ while a candle extension jar was used for the Chacolate for $24 \mathrm{hrs}$. The cultured plates were examined for bacteria using standard methods such as macroscopy, microscopy, biochemical reaction tests.

\subsection{Biochemical Analysis}

Based on cultural characters and Grams reactions, colonies were subjected to motility test using the hanging drop technique; catalase, coagulase, indole, urease Triple sugar iron agar tests and citrate utilization test were done for identification of the isolates to species levels according to ${ }^{21}$

\subsection{Antibiotic Susceptibility Tests}

Identified isolates were tested by disc diffusion methods using antibiotics such as; Amoxycillin $(30 \mu \mathrm{g})$, Ampicillin (10 $\mu \mathrm{g})$, Penicillin G $(30 \mu \mathrm{g})$, cotrimoxazole $(25 \mu \mathrm{g})$, Erthromycin $(5 \mu \mathrm{g})$ Tetracycline $(10 \mu \mathrm{g})$, ciprofloxacin $(5 \mu \mathrm{g})$ and ofloxaxin $(30 \mu \mathrm{g})$. The test and interpretation were carried out according to standard methods $\mathrm{s}^{22,23}$

\subsection{Statistical Analysis}

The chi square test was used to determine the possible association between the variables in the data obtained.

\section{Results}

A total of 345 wound swabs were collected and examined in medical microbiology laboratory in which $243(70.4 \%)$ aerobic bacteria were isolated. In the General outpatient Department 102 specimen were examined, 87(85.3\%) were positive for aerobic bacteria followed by 81 specimen examined from male surgical and $57(70.4 \%)$ were positive, the least was from make medical were 30 specimen were examined and $15(50.0 \%)$ were positive. A total of 196 specimen were from males and $161(82.1 \%)$ were positive for bacteria while of the 149 specimen from females examined, $82(55.0 \%)$ were positive for bacteria. Aerobic bacteria isolated from this study were Staphylococcus aureus $(45.2 \%)$, Klebsiella species (19.4\%), Escherichia coli (12.9\%), Proteus species (12.9\%) and Pseudomonas aeruginosa (9.7\%). Staphylococcus aureus, Klebsiella species, Proteus species, Escherichia coli and Pseudomonas aeruginosawere highly sensitive to ofloxacin but there was reduced susceptibility of the isolates to commonly used antibiotics such as amoxicillin, tetracycline and cotrimoxazole.

Table 1. Prevalence of pathogen in relation to sources of sample

\begin{tabular}{|c|c|c|c|c|}
\hline Source & No. Examined & No. Positive (\%) & Chi-square & P-Value \\
\hline GOPD & 102 & $87(85.3)$ & \multirow[t]{6}{*}{24.485} & \multirow[t]{6}{*}{0.001} \\
\hline Male surgical ward & 81 & $57(70.4)$ & & \\
\hline Female surgical ward & 51 & $30(58.8)$ & & \\
\hline Paediatric surgical ward & 39 & $30(76.9)$ & & \\
\hline Male medical ward & 42 & $24(57.1)$ & & \\
\hline Female medical ward & 30 & $15(50.0)$ & & \\
\hline
\end{tabular}


Table 2. Sex distribution of bacteria isolates from septic wound in Jos

\begin{tabular}{lllll}
\hline Gender & No. Examined & No. Positive (\%) & Chi-square & P Value \\
\hline Male & 196 & $161(82.1)$ & 29.874 & 0.001 \\
Female & 149 & $82(55.0)$ & & \\
Total & 345 & $243(70.4)$ & & \\
\hline
\end{tabular}

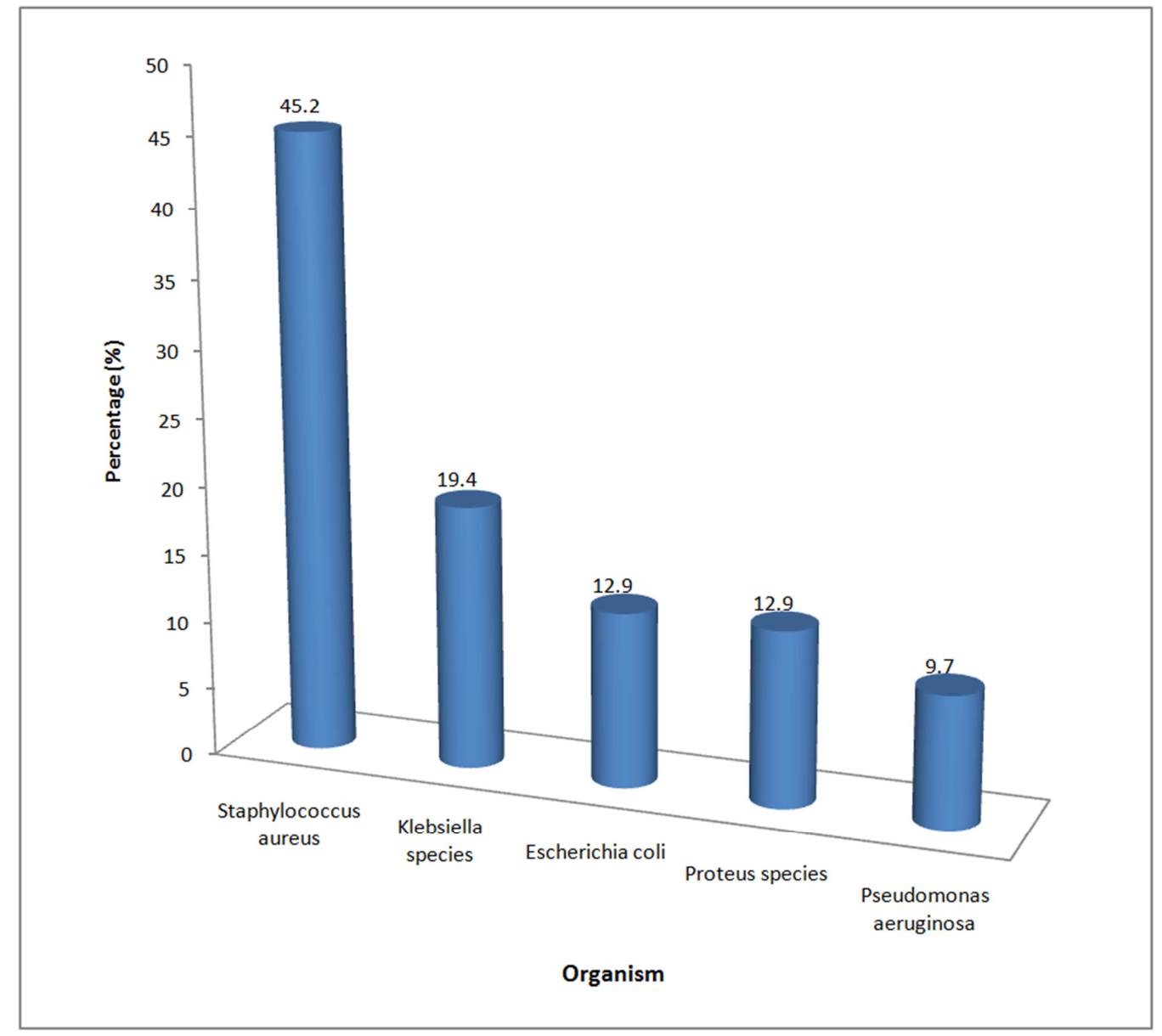

Figure 1. Distribution of aerobic bacteria in septic wound in Jos.

Table 3. Antibiogram of the Isolates in septic wound in Jos.

\begin{tabular}{llllll}
\hline Antibiotics & $\begin{array}{l}\text { S. aureusN=126 } \\
\text { NS (\%) }\end{array}$ & $\begin{array}{l}\text { Klebsiella speciesN=54 } \\
\text { NS (\%) }\end{array}$ & $\begin{array}{l}\text { Proteus species } \mathbf{N}=\mathbf{3 6} \\
\text { NS (\%) }\end{array}$ & $\begin{array}{l}\text { E. coli } \mathbf{N}=\mathbf{3 6} \\
\text { NS }(\%)\end{array}$ & $\begin{array}{l}\text { Pseudomonasaeruginosa } \mathbf{N}=\mathbf{2 7} \\
\text { NS (\%) }\end{array}$ \\
\hline AMC & $39(31.0)$ & $38(70.4)$ & $31(86.1)$ & $33(91.7)$ & $0(0.0)$ \\
AMX & $9(7.1)$ & $7(13.0)$ & $27(75.0)$ & $25(69.4)$ & $0(0.0)$ \\
E & $75(59.5)$ & NT & NT & NT & NT \\
PN & $21(16.7)$ & NT & NT & NT & NT \\
COT & $33(26.2)$ & $8(14.8)$ & $21(58.3)$ & $19(52.8)$ & $0(0.0)$ \\
CN & $54(42.9)$ & $28(51.9)$ & $27(75.0)$ & $30(83.3)$ & $0(0.0)$ \\
CIP & $84(68.8)$ & $47(80.0)$ & $33(91.7)$ & $32(88.9)$ & $0(0.0)$ \\
CHL & $86(68.3)$ & $31(57.4)$ & $23(42.6)$ & $25(69.4)$ & $0(0.0)$ \\
OFX & $96(76.2)$ & $47(87.0)$ & $34(94.4)$ & $34(94.4)$ & $21(77.8)$ \\
\hline
\end{tabular}

KEY: NS $=$ Number test, $\mathrm{NT}=$ Not tested, $\mathrm{AMC}=$ Amoxicillin and clavulanate, $\mathrm{AMX}=$ Amoxicilline, $\mathrm{E}=$ Erythromycin, $\mathrm{PN}=\mathrm{Penicillin}, \mathrm{COT}=\mathrm{Cotrmoxazole}$, $\mathrm{CN}=$ Gentamycin, $\mathrm{CPX}=$ Ciprofloxacilline, $\mathrm{CHL}=$ Chloramphenicol, $\mathrm{OFX}=$ Ofloxacin

\section{Discussion}

The outpatient Department reported the highest prevalent of $85.3 \%$ this prevalence of bacteria in septic wounds is associated with inadequate wound management mostly on the part of the patients. Majority of them will start to manage their wound traditionally and locally at home and only come to the hospital when local management fails. This was followed by male surgical who had $70.4 \%$ of bacterial infection this might be associated with nosocomial infection which are usually prominent in surgical wards because of surgical intervention and operative procedures. There was a 
significant different between the aerobic bacteria isolated from different sections of the hospital $(\mathrm{P}<0.05)$. Our finding is in consonant with previous report ${ }^{1,2}$

In this study males had the highest prevalence of $82.1 \%$ compared with the females who had $55.0 \% \mathrm{P}<0.05$. This findingcorresponds with documented records ${ }^{24,25,26,27,28}$ This finding might be associated to the fact that in our culture males are mostly involves in activities such as farming, carpentry, mechanics, transportation which exposes them to trauma than the females.

This studied showed that isolates reported in this study were Staphylococcus aureus, Klebsiella species, Escherichia coli, Proteus species and Pseudomonas aeruginosa this findings corresponds with other people work ${ }^{1,15}$

Staphylococcus aureus was the most frequent pathogen $45.2 \%$ followed by Klebsiella species $19.4 \%$, our results showed thatStaphylococcus aureuswas the most predominant pathogen which agrees with quite a number of previous report 24, 29, 30,31,32. The high level of Staphylococcus aureus might be associated with the fact that it is an endogenous source of infection and can also be contaminated from the environment. Wound which is the disruption of natural skin barriers, $S$. aureusis a common bacterium on surfaces and can easily find their way into the abrasion on human skin to cause infection.

This study showed that the most frequent Gram negative bacteria is Klebsiella species (19.4\%) which contradict earlier report ${ }^{2}$ which stated that Pseudomonas aeruginosa was the most frequent. Mohamandama ${ }^{24}$ reported thatEscherichia coliwas the most common. Our study showed the changing trends of organisms isolated from septic wounds in the study area. It is therefore pertinent to always carried out similar research to determine current pattern of organism in our environment. This will greatly help in giving empirical treatment to emergency cases.

This study showed that Staphylococcus aureus gave high sensitivity to ofloxacin $(76.2 \%)$, while Ciprofloxacin and chloramphenicol had $68 \%$ this results is similar documented report ${ }^{33}$ However $S$. aureusrevealed lower sensitivity to most commonly used antibiotic such as penicillin(16.7\%) cotrimoxazole (26.2\%) and Amoxicillin (31.0\%) these finding are similar to previous studies ${ }^{33}$ this might be associated with the fact that most $S$. aureus in the study area produces $\beta$ lactamase enzymes. Pseudomonas aeruginosa is a major problem in the study area as it was only sensitive to ofloxacin $(77.8 \%)$ all the other Antibiotic tested were resistant, our finding corresponds with the report of ${ }^{34}$ This resistant rate might be associated with the irrational and inappropriate use of Antibiotic.Escherichia coli was sensitive to all antibiotic use in this study. Klebsiella species showed good sensitivity to ofloxacin( $87.0 \%$ ), Ciprofloxacin( $80.0 \%$ ) and Amoxicillin (70.4\%) but also showed reduced sensitivity to Amoxicillin (13,0\%) Cotrimoxazole (14.8\%) this result is also similar to reported studies ${ }^{34}$

We have demonstrated a current shift in the prevalence of bacteria in septic wound in the study area and also the antibiotic sensitivity pattern of the isolates to guide clinicians to give empirical treatment in emergency situation and very important in formulation of drug policy.

\section{Acknowledgement}

We appreciate the funds from Faith Medical Diagnostic center for this study. We are indeed very grateful to all the patients who willingly give consent to be part of the study. We thank all the Doctors and the nurses in the dressing room and the various surgical and medical wards who gave us maximum cooperation during this study.

\section{References}

[1] Lateef O.A. Thanni ; Olubunmi A. Osinupebi,; and Mope Deji-Agboola, (2003) Prevalence of bacterial pathogens in infected wounds in a tertiary hospital, Journal of the National Medical Association 95(12)1189-1192

[2] Rama Sikka, JK Mann, Deep, MG Vashist, Uma Chaudhary, Antriksh Deep (2012) Prevalence and Antibiotic Sensitivity Pattern of Bacteria Isolated from Nosocomial Infections in a Surgical Ward Indian Journal of Clinical Practice, 22(10), 519-525

[3] Hackner, S. M. (1994) Common infection of the skin: characteristics, causes, and cures. Postgrad. Med. 96:43-52.

[4] Janda, J. M., S. L. Abbott, and R. A. Brenden (1997) Overview of the etiologyof wound infections with particular emphasis on community-acquired illnesses.Eur. J. Clin. Microbiol. Infect. Dis.16:189-201.

[5] Kahn, R. M., and E. J. C. Goldstein (1993) Common bacterial skin infections:diagnostic clues and therapeutic options. Postgrad. Med. 93:175-182

[6] Onderdonk, A. B. (1998) Pharmacodynamics and microbiology of tovrafloxacin in animal models of surgical infection. Am. J. Surg. 176:39S-45S.

[7] Condon, R. E., R. W. Haley, J. T. Lee, and J. L. Meakins (1988) Does theinfection control control infection? Arch. Surg. 123:250-256.

[8] Haley, R. W., D. H. Culver, J. W. White, W. M. Morgan, T. G. Emori, V. P.Munn, and T. M. Hooton (1985) The efficacy of infection surveillance andcontrol programs in preventing nosocomial infections in US hospitals. Am. J.Epidemiol.121:182-205.

[9] Garner JS. (1995) CDC guideline for prevention of surgical wound infections, 1985, supersedes, Guide lines for prevention of surgical wound infections Infection control 7(3): 193-2000.

[10] Gaynes R, Culver D, Harran T, Edwards J, Richards C, Tolson J.(2001) Surgical site infection Rates in the United States, 1992-1998. The National Nosocomial Infections surveillance systems, Clinical Infect Disease 33 (2): 569-577.

[11] Melta M, Duhta P, GuptaV.(2007)Bacterial isolates from burns wound infection and their antibio gram : A eight-year study. Indian J. Plastic sung. 40 (1): 1-28. 
[12] Anguzu, J.R, Ohila D.(2007) Drug sensitivity patterns of bacterial isolates from septicpest-operative wounds in a regional referral hospital in Uganda. Afri. Health Scient. 7(3)

[13] Fadeyi A, Adigun I, Rahman G. (2008) Bacteriological pattern of wound isolates in patients with chronic leg ulcer. International Journal Health Res.1(4): 183-188

[14] Sobayo ET, Osoba AO.(1984) Surgical wounds infection in University college Hospital Ibadan. Nigeria Quarterly $J$. Hospital Med. 2:9-14

[15] Sule A, Thanni L, Sule-odu, Olusanya O(2002) Baterial pathogens Associated with infected wounds in Ogun State University Teaching Hospital Sagamu Nigeria. Afri J. Clin. Exp. Microbiology 3(1) : 13-16.

[16] Vega D, Tellado JM,(1999) Evidence-based medicine in antimicrobial surgical prophylaxis Enferm. Infect. Microbiol. Clin; 17:

[17] Hart C, Kariuki S.(1998) Antimicrobial resistance in developing countries resistance in developing countries. British Medical Journal; 317: 647-650

[18] Kernebradikumo Pondei, Beleudanyo G, Fente, Oluwatoyosi Oladapo(2012) Current microbial isolates from wound swabs, their culture and sensitivity patterns at the Niger Delta University Teaching Hospital, Okolobiri, Nigeria (2012) Kesah et al.

[19] Bowler P, Duerden I, Armstrong D (2001) Wound microbiology and associated approaches to wound management. Clinical Microbiot Review14(2): 22-269

[20] Collee, J.G.;R.S. Miles, B. Watt Testes for the identification of bacteria J.G. Collee (Ed.), Mackie and McCartney(1996)Practical Medical Microbiology, Churchill Livingstone, New York, USA

[21] Cheesbrough M (2004) Distric laboratory practice in tropical countries Part 2. Cambridge University Press. Pp 357

[22] Bauer, A.W; W.M.M. Kirby, J.C. Sherris, M. Turch (1966)Antibioticsusceptibility testing by standardized single disk method Am. J. Clin. Pathol., 45: 493

[23] Koneman, E.; Stephen Allen (2008). Diagnostico Microbiologico/ Microbiological diagnosis: Texto Y Atlas En Color/ Text and Color Atlas (Spanish Edition) Spanish

[24] Mohammedaman Mama, Alemseged Abdissa and Tsegaye Sewunet (2014) Antimicrobial susceptibility pattern of bacterial isolates from wound infection and their sensitivity to alternative topical agents at Jimma University Specialized Hospital, South-West Ethiopia Annals of Clinical Microbiology and Antimicrobials, 13:14 1186/1476-0711-1314
[25] Gelaw A(2001)Isolation of bacterial pathogens from patients with postoperative surgical site infections and possible sources of infections at University of Gondar Hospital, Northwest Ethiopia.

[26] Biadglegne F, Abera B, Alem A, Anagaw B(2009): Bacterial isolates from wound infection and their antimicrobial susceptibility pattern in Felege Hiwot Referral Hospital, North West Ethiopia. Ethiop J Health Sci.19(3):173-178.

[27] Ohalete CN, Obi RK, EmeaKoroha MC(2012)Bacteriology of different wound infection and their antimicrobial susceptibility patterns in Imo state Nigeria. World $J$ Pharm Pharm Sci.1(3):1155-1172.

[28] Amoran OE, Sogebi AO, Fatugase OM: Rates and risk factors associated with surgical site infections in a tertiary care center in South-Western Nigeria.

[29] Bhatt C, Lakhey $M(2006)$ : The distribution of pathogens causing wound infection and their antibiotic susceptibility pattern. J Nepal Health Res Council5(1):22-26.

[30] Mulu A, Moges F, Tessema B, Kassu A (2006): Patterns and multiple drug resistance of bacterial pathogens at university of Gondar teaching hospital. Northwest Ethiopia Ethiop Med J, 44(2):125-131.

[31] Mulu W, Kibru G, Beyene G, Damtie M(2012): Postoperative nosocomial infections and antimicrobial resistance pattern of bacteria isolates among patients admitted at Felege Hiwot Referral Hospital, Bahirdar. Ethiopia Ethiop $J$ Health Sci.22(1):7-18.

[32] Emele F, Izomoh M, Alufohai E(1999): Microorganisms Associated With Wound Infection In Ekpoma. Nigeria. West Afr J Med, 18(2):97-100.

[33] Siergrist H, Nepa MC, Jacquet (1999) Susceptibility to Levofloxacin of clinical isolates of bacrteria from intensive care and haematologival/oncology patients in Switzerland: a multicenter study J. Antimicrobchemother4:51-4

[34] Nutambala N, Hiran R. Aipesh Puri P(2011) Antibiotic Sensitivity profile of bacterial pathogens in posy operative wound infections. J phamacol pharmacother 2(3): 158-164 